Article

\title{
Predictability of Seasonal Streamflow in a Changing Climate in the Sierra Nevada
}

\author{
Minxue $\mathrm{He}^{*}$, Mitchel Russo and Michael Anderson \\ Division of Flood Management, California Department of Water Resources, 3310 El Camino Avenue, \\ Sacramento, CA 95821, USA; Mitchel.Russo@water.ca.gov (M.R.); Michael.L.Anderson@water.ca.gov (M.A.) \\ * Correspondence: Kevin.He@water.ca.gov; Tel.: +1-916-574-2221
}

Academic Editors: Daniele Bocchiola, Claudio Cassard and Guglielmina Diolaiuti Received: 1 October 2016; Accepted: 22 November 2016; Published: 25 November 2016

\begin{abstract}
The goal of this work is to assess climate change and its impact on the predictability of seasonal (i.e., April-July) streamflow in major water supply watersheds in the Sierra Nevada. The specific objective is threefold: (1) to examine the hydroclimatic impact of climate change on precipitation and temperature at the watershed scale, as well as the variability and trends in the predictand (i.e., April-July streamflow runoff) and its operational predictors (including 1 April snow water equivalent, October-March precipitation and runoff, and April-June precipitation) in a changing climate; (2) to detect potential changes in the predictability of April-July streamflow runoff in response to climate change; and (3) to assess the relationship between April-July streamflow runoff and potential new predictors and the corresponding trend. Historical records (water year 1930-2015) of annual peak snow water equivalent, monthly full natural flow, monthly temperature and precipitation data from 12 major watersheds in the west side of the Sierra Nevada in California (which are of great water supply interest) are analyzed. The Mann-Kendall Trend-Free Pre-Whitening procedure is applied in trend analysis. The results indicate that no significant changes in both the predictand and predictors are detected. However, their variabilities tend to be increasing in general. Additionally, the predictability of the April-July runoff contributed from each predictor is generally increasing. The study further shows that standardized precipitation, runoff, and snow indices have higher predictability than their raw data counterparts. These findings are meaningful from both theoretical and practical perspectives, in terms of guiding the development of new forecasting models and enhancing the current operational forecasting model, respectively, for improved seasonal streamflow forecasting.
\end{abstract}

Keywords: climate change; seasonal streamflow predictability; Sierra Nevada; California

\section{Introduction}

Reliable forecasts on seasonal streamflow have tremendous economic and environmental worth, ranging from more effective water supply planning [1-3], improved flood and drought management [4-7], and increased hydropower generation [8-10], among others. The worth is particularly evident in semi-arid areas including the State of California, which largely relies on snow melt from the Sierra Nevada to supply water in meeting the State's increasing demand induced from its growing economy and population. Previous studies reported that climate warms lead to declining mountain snowpack and earlier peaked snowmelt-driven streamflow in western North American including the Sierra Nevada region [11-14]. These changes pose unprecedented challenges on regional water resources planning and management practices, which are typically based on the forecast of seasonal streamflow (specifically April-July runoff volume, hereinafter AJ runoff) with lead time up to months. Traditionally statistical regression equations have been applied in operational seasonal streamflow forecasting for major water supply watersheds across the State since around $1930[15,16]$. 
These equations typically relate the predictand (namely AJ runoff) to three categories of operational predictors, including accumulated precipitation in specific periods (October-March and April-June), antecedent streamflow (from October to March), and snow information (snow index relative to 1 April snow water equivalent (A1 SWE)) [16-21]. The predictability of AJ runoff is thus dependent on its relationship with these predictors. This relationship, however, is susceptible to a changing climate which alters the timing and volume of these predictors, particularly in temperature-sensitive elevations of the Sierra Nevada.

A set of studies have been dedicated to investigate the impact of climate change on hydroclimatic variables in regions containing the State of California. In general, these studies either focus on a point scale or on a gridded scale. The former ones typically examine historical observations of interested variables from individual gauges [12,22-26]. The latter ones normally assess gridded data converted from point measurements or through distributed models [27-30]. To our knowledge, few studies have explored the impact of climate change on hydroclimatic variables including the AJ runoff and its operational predictors together (and their relationship) at the (water supply) watershed scale in California, while water resources planning and management actions are generally made at the watershed scale (e.g., reservoir inflows contributed from water supply watersheds) [31]. Similarly, few studies have investigated the impact of climate change on the predictability of seasonal streamflow in the State.

In addition to operational predictors, much research has devoted to identify and apply new predictors including standardized (precipitation, runoff, snow) indices and large-scale climate indices in seasonal streamflow forecasting, due to their potential in reflecting historical or future climate and weather conditions [32-45]. Yet holding great potential in improving the current forecasting, these indices' relationship with seasonal streamflow has not been explicitly explored in major water supply watersheds in California. The response of this relationship to a changing climate also remains unexplored.

The goal of this work is to fill the above mentioned gaps by addressing the following science questions: (1) how is the predictability of seasonal streamflow (from both operational and research predictors) in major water supply watersheds in the Sierra Nevada impacted by climate change? (2) what is the implication of this impact to operational seasonal streamflow forecasting practices? The specific objective is threefold: (1) to examine the hydroclimatic impact of climate change on precipitation and temperature at the watershed scale, as well as the variability and trends in the predictand (i.e., April-July streamflow runoff) and its operational predictors in a changing climate; (2) to detect potential changes in the predictability of April-July streamflow runoff in response to climate change; and (3) to assess the relationship between April-July streamflow runoff and potential new predictors and the corresponding trend.

\section{Materials and Methods}

\subsection{Study Area and Dataset}

This study focuses on 12 snow fed watersheds in the western slope of the Sierra Nevada in the State of California (Figure 1; Table 1), including four watersheds from each of the three hydrologic regions located in the Central Valley. These regions are, from north to south, Sacramento Region (SBB, FTO, YRS, AMF), San Joaquin Region (SNS, TLG, MRC, SJF) and Tulare Region (KGF, KWT, SCC, KRI). Water from these watersheds is a major source of the State's water supply. Monthly full natural flow (FNF) and annual 1 April snow water equivalent (SWE) data of an 86-year period (water years 1930-2015) for these watersheds are obtained from the California Data Exchange Center (http:/ / www.cdec.water.ca.gov/) for this study. Monthly precipitation and temperature (including maximum, minimum and average temperature) data at 4-kilometer resolution were downloaded from the PRISM (http:/ / www.prism.oregonstate.edu/) and averaged to the watershed scale during the same period. 


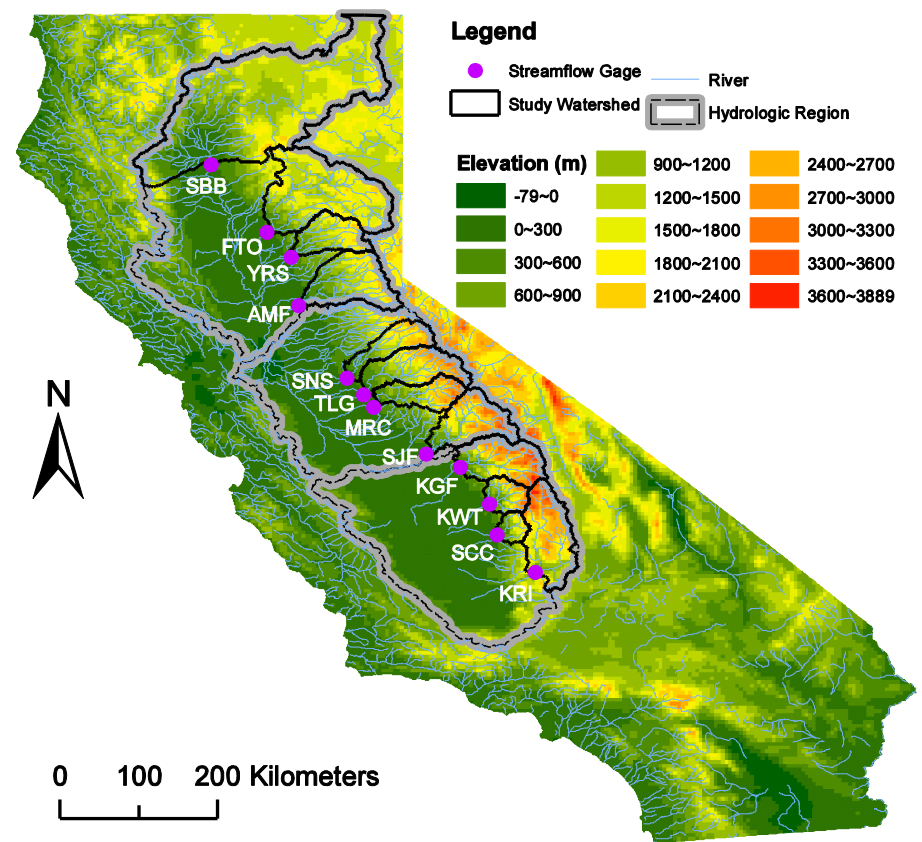

Figure 1. Location map showing study watersheds in the State of California.

Table 1. Hydroclimatic characteristics of study watersheds.

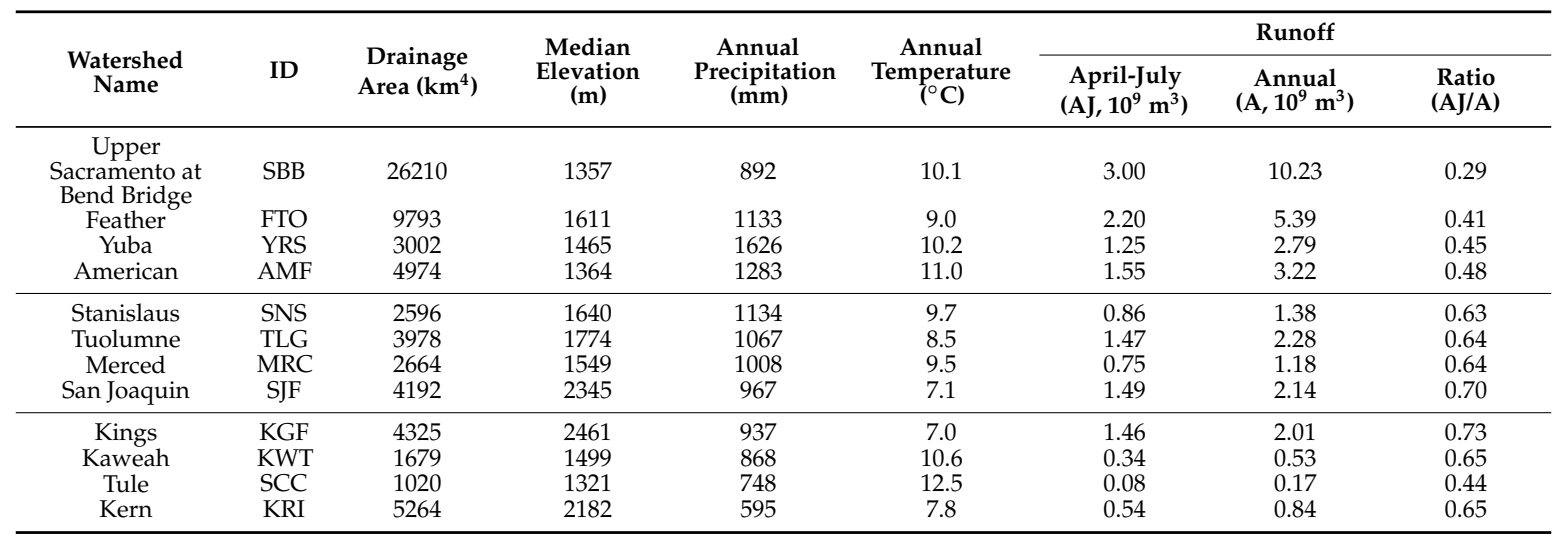

The study watersheds have similar hydroclimatic characteristics. The Upper Sacramento River at Bend Bridge (SBB) and the Tule River Watershed (SCC) are the largest and smallest watersheds, respectively, in terms of size and runoff generation (Table 1). In general the northern watersheds have lower elevations (Figure 1; Table 1) and are less snow impacted (measured by AJ runoff to annual runoff ratio; Table 1) in comparison to the southern watersheds except for SCC. Opposite to the Kings River Watershed (KGF) which has the most significant snow dominance, the SBB is least impacted by snow. The KGF (SCC) has the highest (lowest) median elevation and lowest (highest) annual temperature. The Yuba River Watershed (YRS) is the wettest watershed with regards to average annual precipitation received, while the Kern River Watershed (KRI) is the driest watershed (Table 1).

Despite their differences in hydroclimatic characteristics, these study watersheds share a similar seasonality in precipitation and temperature (Figure 2). The majority of annual precipitation occurs in the wet season from November-April, ranging from $81 \%$ (SBB) to $89 \%$ (SCC). All the watersheds receive the highest amount of precipitation in December (for SBB and YRS) or January (for other watersheds). In contrast, the percentage of summer (June-August) precipitation over the annual precipitation varies from $1.7 \%$ (SCC) to $5.1 \%$ (SBB). The highest temperature consistently appears in July, varying from $16.6{ }^{\circ} \mathrm{C}$ (KGF) to $22.2{ }^{\circ} \mathrm{C}$ (SCC). The lowest temperature typically occurs in 
January, ranging from $-0.2^{\circ} \mathrm{C}$ (KGF and San Joaquin, SJF) to $4.8^{\circ} \mathrm{C}$ (SCC). Overall, the SCC (KGF) is the warmest (coolest) watershed. The YRS (KRI) is the wettest (driest) watershed. These observations are consistent with what have been observed on the annual scale (Table 1).
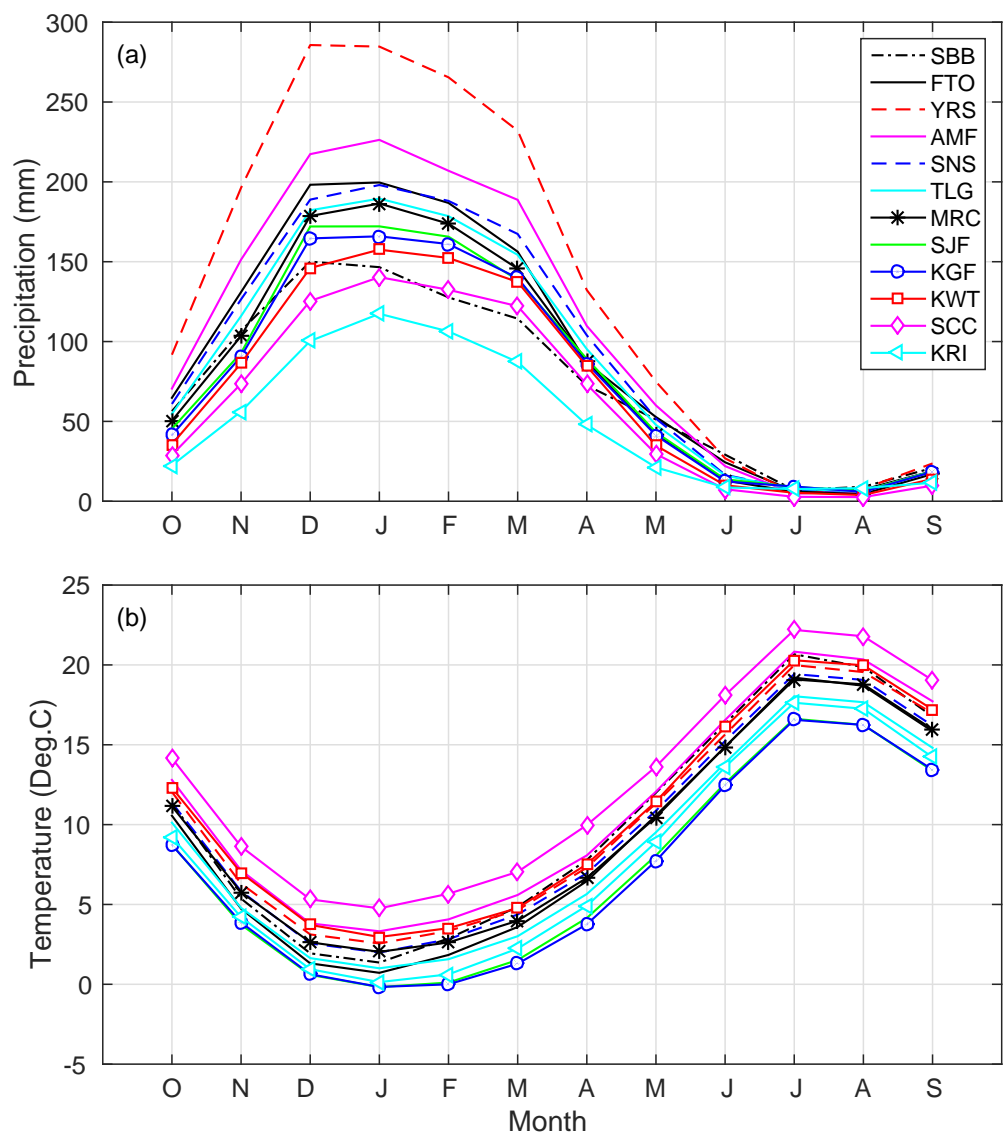

Figure 2. (a) Mean monthly precipitation; and (b) mean monthly average temperature of the study watersheds for October (O), November (N), December (D), January (J), February (F), March (M), April (A), May (M), June (J), July (J), August (A), and September (S).

\subsection{Potential Predictors}

It has been long recognized in the research community that large-scale teleconnection indices have non-negligible relationship with precipitation and streamflow in the Western US [32], given the fact that future climate and weather conditions are often connected with those indices. Particularly, four teleconnection indices (with long record since at least early last century) were shown to have notable relationship with streamflow and thus have been commonly applied in climate monitoring in this region [34,46-49]. These indices include the Niño 3.4 Sea Surface Temperature Index (Niño 3.4), the Trans-Niño Index (TNI), the Southern Oscillation Index (SOI) and the Pacific Decadal Oscillation (PDO) index. This study examines the predictability of AJ runoff coming from these indices and compares it with the existing operational predictors. Monthly time series of these indices are obtained from the website of the Earth System Research Laboratory (ESRL) of the U.S. National Oceanic and Atmospheric Administration (NOAA) (http://www.esrl.noaa.gov/). A detailed description on these indices is also available on the website.

A large number of standardized indices have been developed in water resources planning and management practices including drought monitoring, assessment and prediction [50-52]. Among these indices, the Standardized Precipitation Index (SPI) [53] and Standardized Runoff Index (SRI) [54] are widely employed as indicators of meteorological and hydrologic dryness (or wetness), respectively. 
These indices are typically developed by fitting a preset probability distribution function (e.g., Gamma distribution) to precipitation and streamflow data. The cumulative distribution obtained is then transformed to the Cumulative Distribution Function (CDF) of the standard normal distribution to drive a standardized index. A positive (negative) index value indicates wet (dry) conditions. In spite of their advantageous standardized nature and their flexibility of use across different spatial and temporal scales [5], there is no consensus on which distribution function fits the data best $[55,56]$. For a specific distribution function, its parameters need to be estimated based on the data fed and tend to be impacted by the length of the data record period. In light of these observations, a generalized framework in deriving nonparametric standardized indices entitled Standardized Drought Analysis Toolbox (SDAT) is developed [57]. This approach uses the empirical Gringorten plotting position in deriving the marginal distribution of the target variable. The empirical probability of the variable is then transformed into a standardized value. This method requires no assumption on a parametric distribution function and thus no parameter estimation. For a detailed description on the SDAT, the readers are referred to [57]. This study adopts SDAT in calculating nonparametric standardized indices for precipitation, runoff, and snow at designated time scales (e.g., October-March, April-June, April-July, 1 April).

\subsection{Trend Analysis}

This study employs the widely used non-parametric Mann-Kendall test (MKT) [58,59] in assessing the significance of a trend. The MKT first calculates the sign of each possible pair of observations and then determine the corresponding test statistic $\delta$. The null hypothesis $\mathrm{H}_{0}$ of no trend is rejected if $|\delta|>\delta_{1-\alpha / 2}$, where $\delta_{1-\alpha / 2}$ is the probability of the standard normal distribution at a significance level of $\alpha$. A value of 0.05 for $\alpha$ is applied throughout the study. The alternative hypothesis that a monotonic trend exists is favored under this condition. A positive (negative) value of $\delta$ indicates an increasing (decreasing) trend. The non-parametric Theil-Sen approach (TSA) $[60,61]$ is used in the study to identify the slope of significant trends determined via the MKT.

Some previous studies [62-64] noticed that the presence of positive serial correlation increases the probability of false rejection of the null hypothesis of no trends. To obtain more robust trend analysis results, this study employs a trend-free pre-whitening procedure (TFPW) [65-67] to address the serial correlation. The original time series with a significant trend (determined via the MKT with a significance level of 0.05) is first de-trended. A lag-one auto-regressive process is then removed from the de-trended time series to generate a new time series. The trend determined from the original time series is added to the new one, yielding a combined time series. For a detailed explanation on the TFPW procedure, the readers are referred to [65].

\subsection{Study Metrics}

This study employs a parsimonious metric to represent the variability: the normalized variance of a target variable (precipitation, temperature, streamflow and A1 SWE) over the period of record. The metric is calculated as the ratio of the sub-period variance of the variable to its corresponding long-term variance. A ratio above one indicates that the target variable in the sub-period becomes more variable than usual. This metric has been extensively applied in assessing variability in hydro-climatic variables. For instance, $[15,68]$ investigated streamflow variability in every 20 -year sub-period within the record period for a large number of watersheds in the Western U.S. They used a jackknife procedure in verifying the significance of the variability in streamflow. They argued that a 20-year window provides enough sample size to develop reliable variances and persistence, although a longer period would be more desirable. Most recently, [31] examined the variability of temperature and precipitation in seven climatic divisions of California using a 30-year window. The current study has an 86-year record of period (from water years 1930-2015). A 20-year window (sub-period) is applied.

Following [69-72], this study employs the linear Pearson correlation coefficient as the metric quantifying the strength of predictability. An increasing (decreasing) tendency in the correlation 
coefficient indicates increasing (decreasing) predictability. Specifically, the study investigates the predictability of AJ runoff (AJ FNF) derived from A1 SWE, OM runoff (OM FNF), October-March precipitation (OM Ppt) and April-June precipitation (AJun Ppt), respectively. The predictability of the standardized AJ FNF index attributed from standardized A1 SWE index, standardized OM FNF index as well as standardized precipitation indices determined from OM Ppt and AJun Ppt is also investigated. A 20-year moving window is applied in the analysis, following the concept of [68] in determining the variability. However, to explore the impact of the window size on the results, a set of different sizes including 30-, 40-, 50-, and 60-year of moving window are also examined.

\section{Results}

As stated in Section 1, the specific objective of this study is threefold. The results are accordingly grouped and presented in three parts. In the first part (Section 3.1), variabilities of the predictand (AJ FNF) and its operational predictors (i.e., A1 SWE, OM FNF, OM Ppt and AJun Ppt) are first examined. Furthermore, trends in these variabilities are explored. Trends in those variables along with precipitation and temperature are also investigated. In the second part (Section 3.2), predictability of the predictand is first assessed, followed by the trend in the predictability. The third part (Section 3.3) differs from the second part in that it focuses on the potential predictors including standardized indices and large-scale climate indices rather than the operational predictors.

\subsection{Variability and Trend}

A general increasing and then decreasing pattern is evident in the variabilities of AJ FNF, A1 SWE, OM FNF and OM Ppt for all the study watersheds (Figure 3). The peak variability value normally occurs within the period from 1980 to 2000. In comparison, a rough cyclic increasing-decreasing-increasing pattern in the study period is notable for AJun Ppt. The lowest variability typically occurs in the window 1980-2000. This contrast between the variabilities in AJun Ppt and other variables likely stem from the fact that the latter (A1 SWE, OM FNF and AJ FNF) heavily relies on the wet season precipitation (OM Ppt) which is considerably different from AJun Ppt in amount (Figure 2a). This further implies that the wet season precipitation varies differently from the AJun Ppt in the study period. It is also worth noting that the variation patterns of the AJ FNF variability, OM Ppt variability and A1 SWE variability for San Joaquin and Tulare watersheds (Figure 3e-l) are fairly close to each other, while it is a different case for watershed in the Sacramento region (Figure 3a-d). This observation indicates that the AJ FNF has a relatively stronger relationship with A1 SWE and OM Ppt in San Joaquin and Tulare watersheds than with those in the Sacramento watersheds.

Results of the Mann-Kendall Trend-Free Pre-Whitening procedure are presented in Figure 4. Increasing trend in the variability of OM FNF is observed at all study watersheds, with the highest ( $0.247 /$ decade) and lowest $(0.039 /$ decade) increasing rates occurring at the most Southern watershed (KRI) and the most Northern watershed (SBB), respectively. Increasing tendency in the variability of AJ FNF is also evident for all study watersheds except for KRI. On average, the increasing slope is milder than that of the variability of OM FNF. Significant trends are observed in the variability of A1 SWE at seven study watersheds of which two (AMF and SNS) have decreasing trends, while the remaining watersheds have upward trends. Increasing variability in OM Ppt is also distinct at most study watersheds except for three most Southern ones (KWT, SCC and KRI). In contrast, an increasing tendency in the variability of AJun Ppt is noticeable at only five most Southern watersheds (SJF, KGF, KWT, SCC and KRI). The trends observed in (OM and AJun) precipitation variability have relatively milder slopes compared to their counterparts in (OM and $\mathrm{AJ})$ flow variability. 

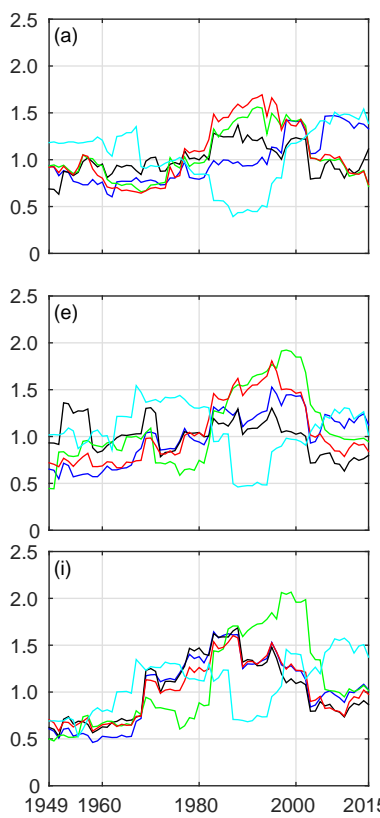
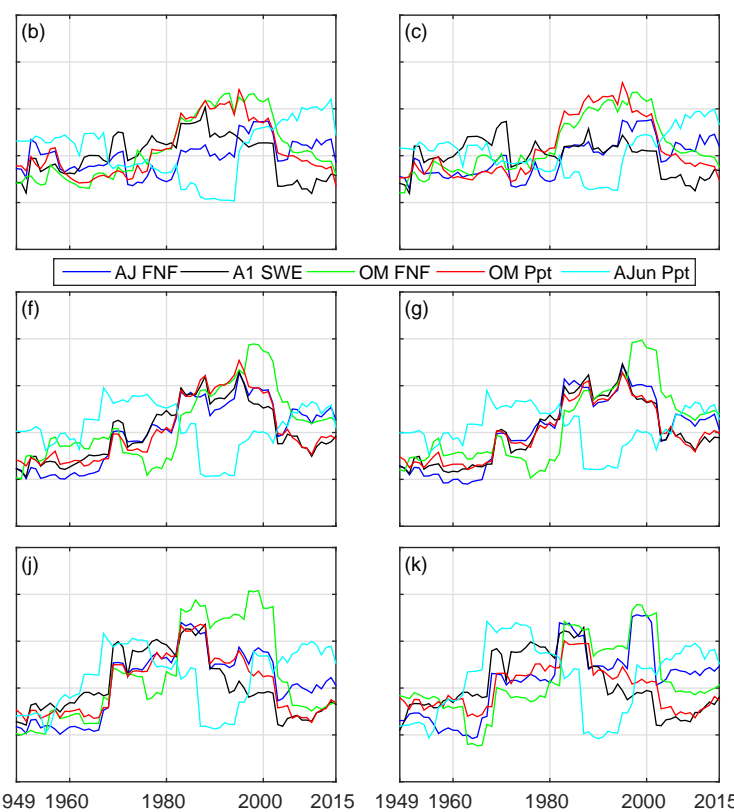
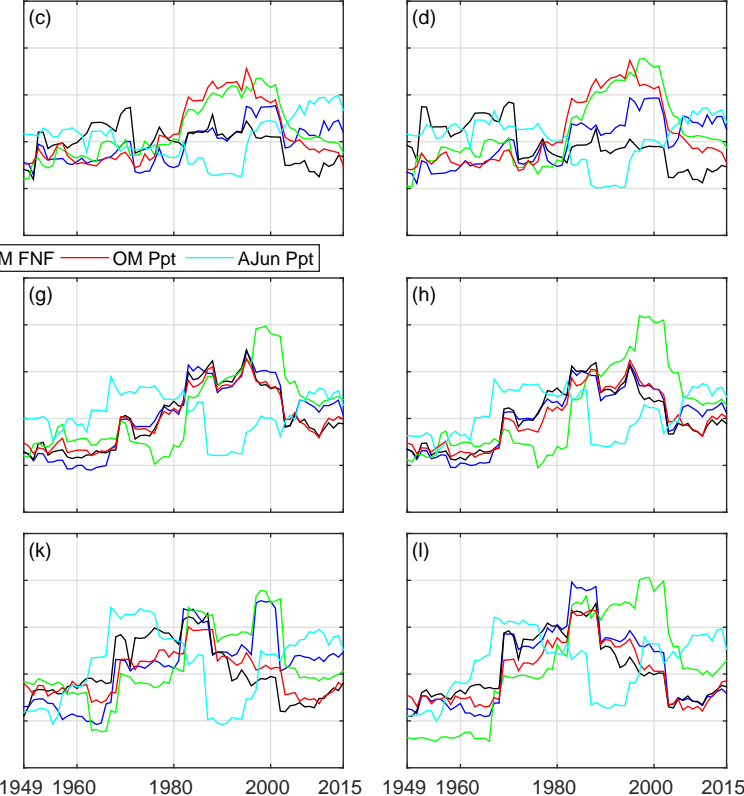

Figure 3. Time series of the 20-year moving window of variability of April-July runoff (AJ FNF), 1 April SWE (A1 SWE), October-March runoff (OM FNF), October-March precipitation (OM Ppt) and April-June (AJun Ppt) from 1949-2015 for study watersheds (a) SBB; (b) FTO; (c) YRS; (d) AMF; (e) SNS; (f) TLG; (g) MRC; (h) SJF; (i) KGF; (j) KWT; (k) SCC; (l) KRI. The X-axis and Y-axis show the end-year of the moving window and the variability value, respectively.

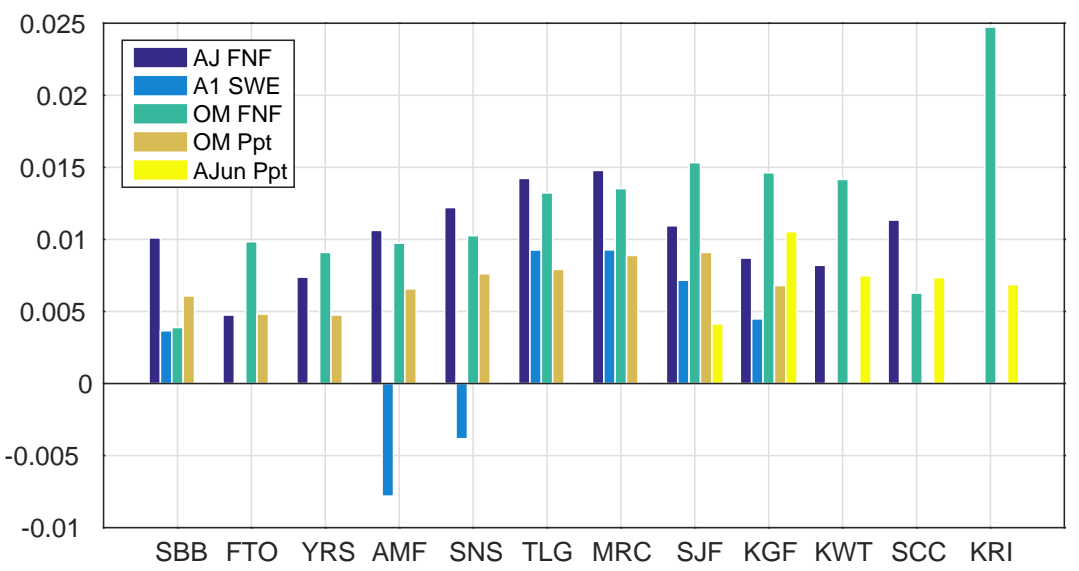

Figure 4. Trend slope (per year; Y-axis) in variability of April-July runoff (AJ FNF), 1 April SWE (A1 SWE), October-March runoff (OM FNF), October-March precipitation (OM Ppt) and April-June precipitation (AJun Ppt) from 1949-2015 for study watersheds (X-axis).

In addition to the variability, trend analysis is also conducted for precipitation and temperature at different temporal scales as well as for the predictand and predictors themselves. Increasing trends in annual average temperature are noticeable across all study watersheds (Figure 5a), with increasing rates ranging from $0.011^{\circ} \mathrm{C} /$ year $(\mathrm{SBB})$ to $0.021^{\circ} \mathrm{C} /$ year $(\mathrm{SCC})$. The upward trends are also evident in Summer temperature, with the mildest slope $\left(0.014^{\circ} \mathrm{C} /\right.$ year $)$ occurring at the most Northern watershed (SBB) and the steepest slope $\left(0.021^{\circ} \mathrm{C} /\right.$ year $)$ at another Southern watershed (KWT). In other three seasons (Fall, Winter and Spring), three most Southern watersheds (KWT, SCC and KRI) along with FTO, AMF and MRC exhibit consistent upward trends in average temperature. The tendency is the most significant at SCC where trend slopes are consistently above $0.020{ }^{\circ} \mathrm{C} /$ year. In comparison, four other watersheds including SBB, YRS, TLG and SJF only show increasing trend in Winter. Different 
from the case of average temperature, only two most Southern watersheds (SCC and KRI) have increasing trends in annual, Spring and Summer maximum temperature (Figure $5 b$ ). There is no significant trend in Fall maximum temperature at any watershed. Additionally, increasing trend in winter maximum temperature is only observed at SCC. In contrast, increasing trends in minimum temperature are observed at both annual and seasonal scales at all study watersheds (Figure $5 \mathrm{c}$ ). The increases in Summer and Spring are the most and least significant, with mean slopes at $0.030{ }^{\circ} \mathrm{C}$ /year and $0.020^{\circ} \mathrm{C} /$ year (versus $0.025{ }^{\circ} \mathrm{C}$ /year at the annual scale) across the study watersheds, respectively. Trends in precipitation at annual and seasonal scales are also investigated. However, no watersheds show any significant increasing or decreasing tendency with the exception of SCC that shows a decreasing trend (at a rate of $-0.18 \mathrm{~mm} / \mathrm{yr}$ ) in annual precipitation. However, this rate is very small compared to the annual precipitation the watershed receives on average (Table 1).
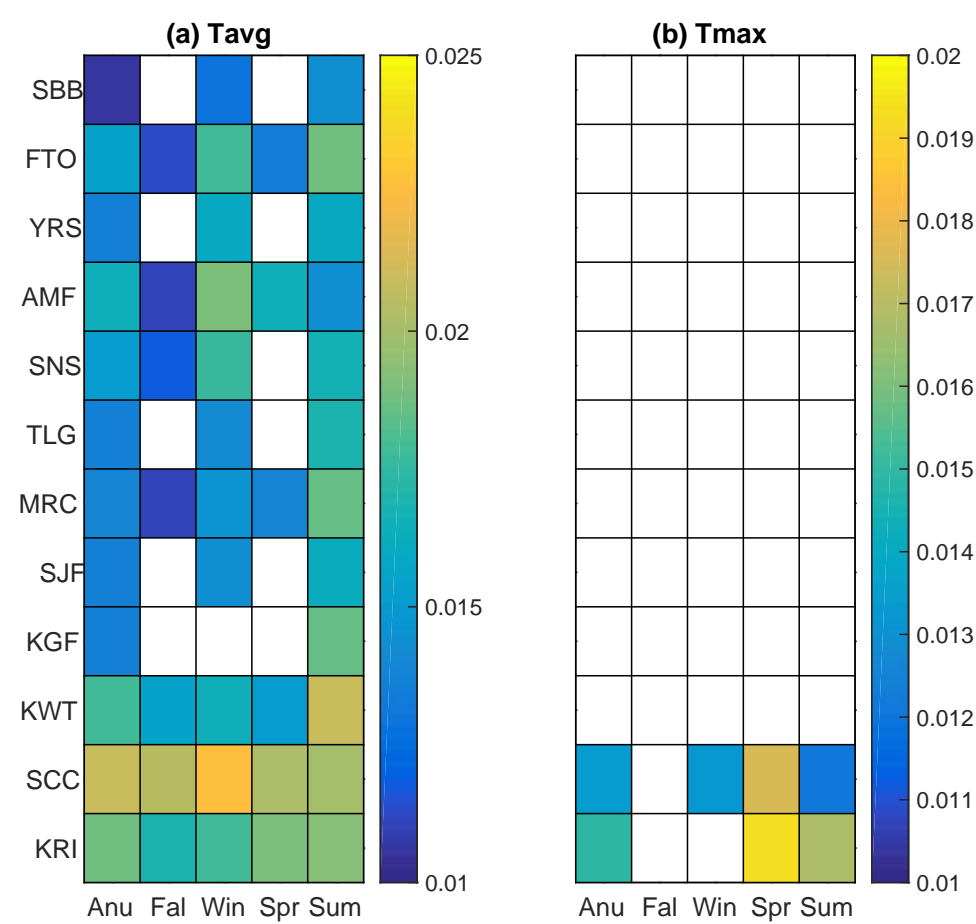

(c) Tmin

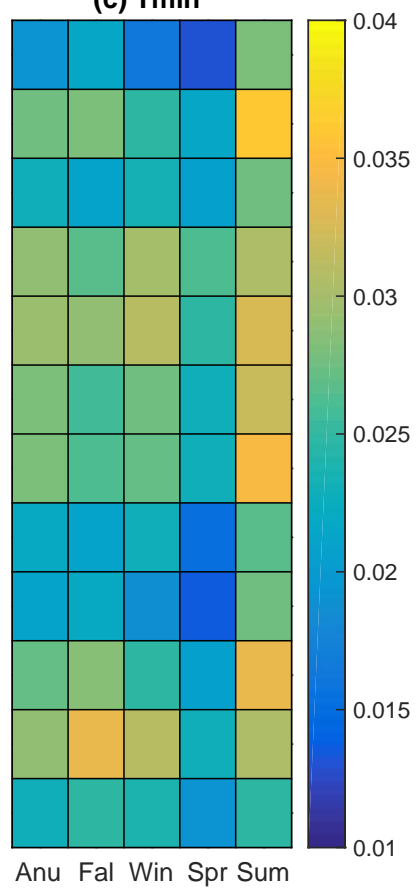

Figure 5. Slope $\left({ }^{\circ} \mathrm{C} /\right.$ year $)$ of significant trends in (a) average annual and seasonal temperature; (b) maximum annual and seasonal temperature; (c) minimum annual and seasonal temperature observations in the study period (water years 1930-2015). The white color indicates no statistically significant trends. The $\mathrm{X}$-axis and $\mathrm{Y}$-axis show the temporal scale and study watersheds, respectively. "Anu", "Fal", "Win", "Spr" and "Sum" stand for Annual, Fall, Winter, Spring and Summer, respectively.

Aside from annual and seasonal scales, the trends of temperature and precipitation are further examined at the monthly scale (Figure 6). In November, December, and April, monthly average temperature shows no trends in any study watersheds, while positive (increasing) trends are evident in January, August and September at all watersheds (Figure 6a). In October and May, only two Southern watersheds (SCC and KRI) exhibit increasing tendency in average temperature. In comparison, trends are limited spatially and temporally in monthly maximum temperature (Figure $6 \mathrm{~b}$ ). In five months (October-December, April and July), maximum temperature shows no upward or downward trend at any watershed. In May and August, only SCC observes increasing tendency; in March and September, only SCC and KRI have positive trends. Two watersheds (TLG and MRC) observe no trends in any month. Differently from average temperature and maximum temperature, minimum temperature exhibits increasing trends in most months, with the exception being December and April when only three watersheds (AMF, SNS and SCC) and one watershed (AMF) display significant upward 
trends, respectively (Figure 6c). Comparing three temperature variables, the trends in the minimum temperature are generally the most significant (with steeper trend slopes). These observations are consistent with the case at the annual and seasonal scale (Figure 5). Across all months, December and April tend to have the least amount of watersheds with significant trends in temperatures. In comparison, the trends in January are generally the most significant. For precipitation, only a few (three) watersheds exhibit upward trends in July and August. However, the increasing rates are generally very small compared to the annual precipitation occurring to these watersheds. Moreover, July and August are dry months when only a small portion $(<3 \%)$ of the annual precipitation occurs (Figure 2). These increasing trends thus seemingly have limited implications from water supply's perspective. Trend analysis is further conducted for the predictand (AJ FNF) and its operational predictors (A1 SWE, OM FNF, OM Ppt and AJun Ppt). The results indicate that no statistically significant changes exist in these variables in the period from water year 1930-2015.

(a) Tavg

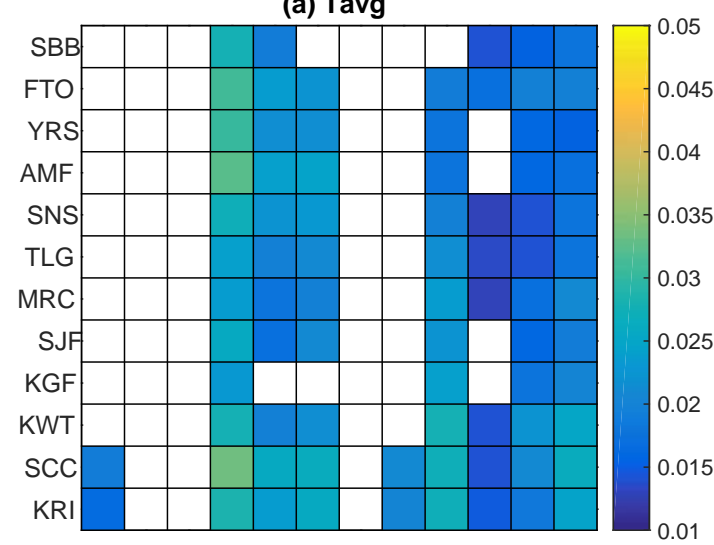

(c) Tmin

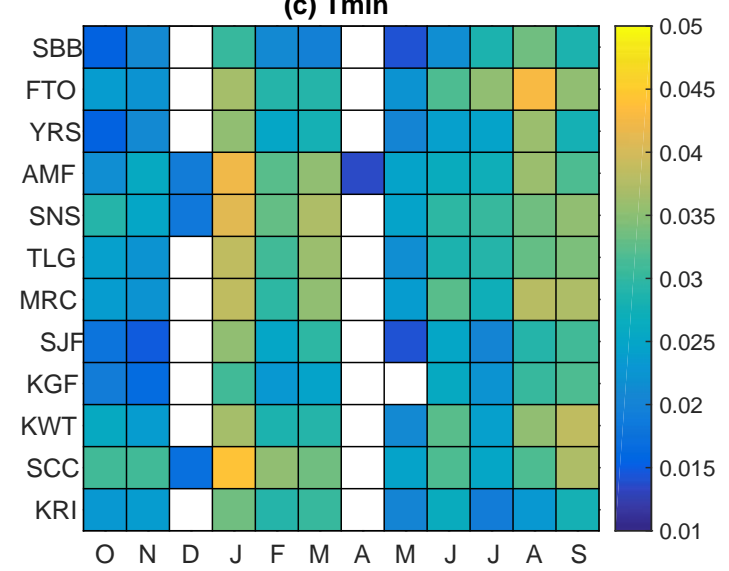

(b) Tmax

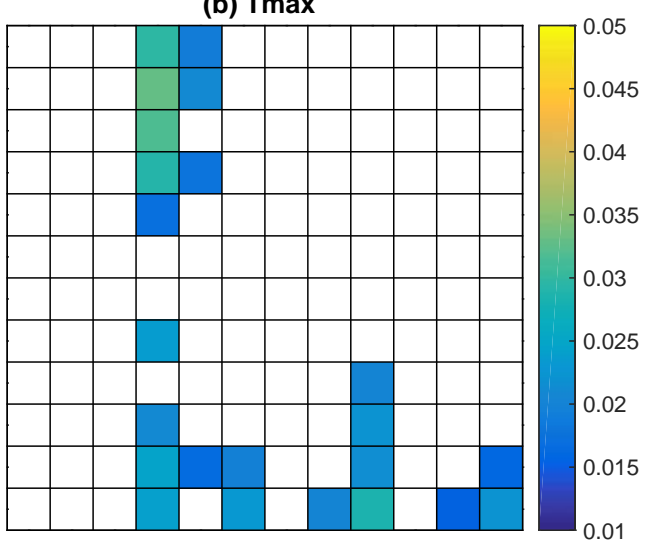

(d) Ppt

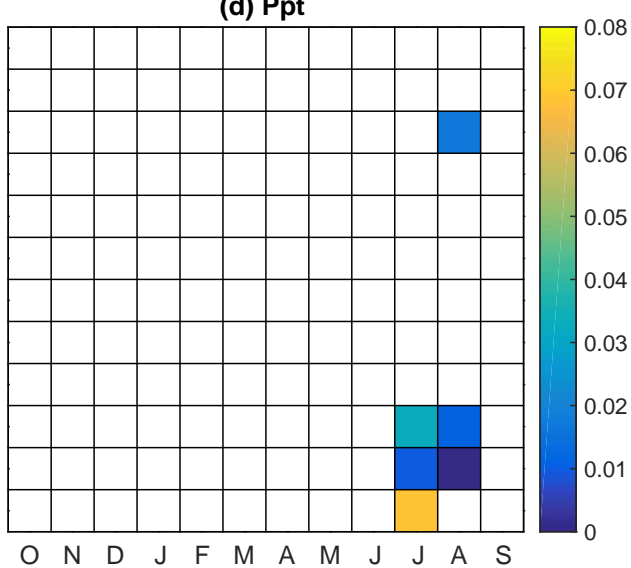

Figure 6. Slope of significant trends in (a) average temperature $\left({ }^{\circ} \mathrm{C} /\right.$ year); (b) maximum temperature ( ${ }^{\circ} \mathrm{C} /$ year); (c) minimum temperature $\left({ }^{\circ} \mathrm{C} /\right.$ year); $(\mathrm{d})$ precipitation $(\mathrm{mm} /$ year) observations at the monthly scale in the study period (water years 1930-2015). The X-axis and Y-axis show the months (explained in Figure 2's caption) and study watersheds, respectively.

In general, increasing tendency is detected in the minimum temperature and the average temperature. The changes in the maximum temperature and precipitation across annual, seasonal and monthly scales are limited. No changes are identified in the predictand and predictors. However, their variabilities generally exhibit increasing trends with an exception in the variability in A1 SWE at two study watersheds. 


\subsection{Predictability from Operational Predictors}

This sub-section first explores the predictability of the AJ FNF contributed from different operational predictors. Assessment of potential trends in the predictability is conducted afterwards. The correlations between AJ FNF and four predictors in a 20-year moving window for all study watersheds are calculated (Figure 7). Overall, the correlations with A1 SWE and OM Ppt are higher than that with the remaining two predictors (OM FNF and AJun Ppt), highlighting that A1 SWE and OM Ppt are the primary predictors. Region-wise, the correlation between AJ FNF and A1 SWE is the highest for the San Joaquin Region (Figure 7e,f) with the median region-wide (averaged over four watersheds in the region) correlation value of 0.90 . In contrast, the lowest correlation occurs over the Sacramento Region (Figure 7a-d) with a median value of 0.81 . The correlation with OM FNF and the correlation with OM Ppt over the Sacramento Region are also the lowest, with the median correlation values at 0.62 and 0.79 , respectively. In both cases, the highest correlations occur over the Tulare Region (Figure 7i-1) with the median correlation values being 0.73 and 0.89 , respectively. Looking at predictor AJun Ppt, however, the correlation over the Tulare Region (Sacramento Region) is generally the lowest (highest), indicating that AJ runoff over the Tulare Region is more snow dominated and less impacted by AJun precipitation.
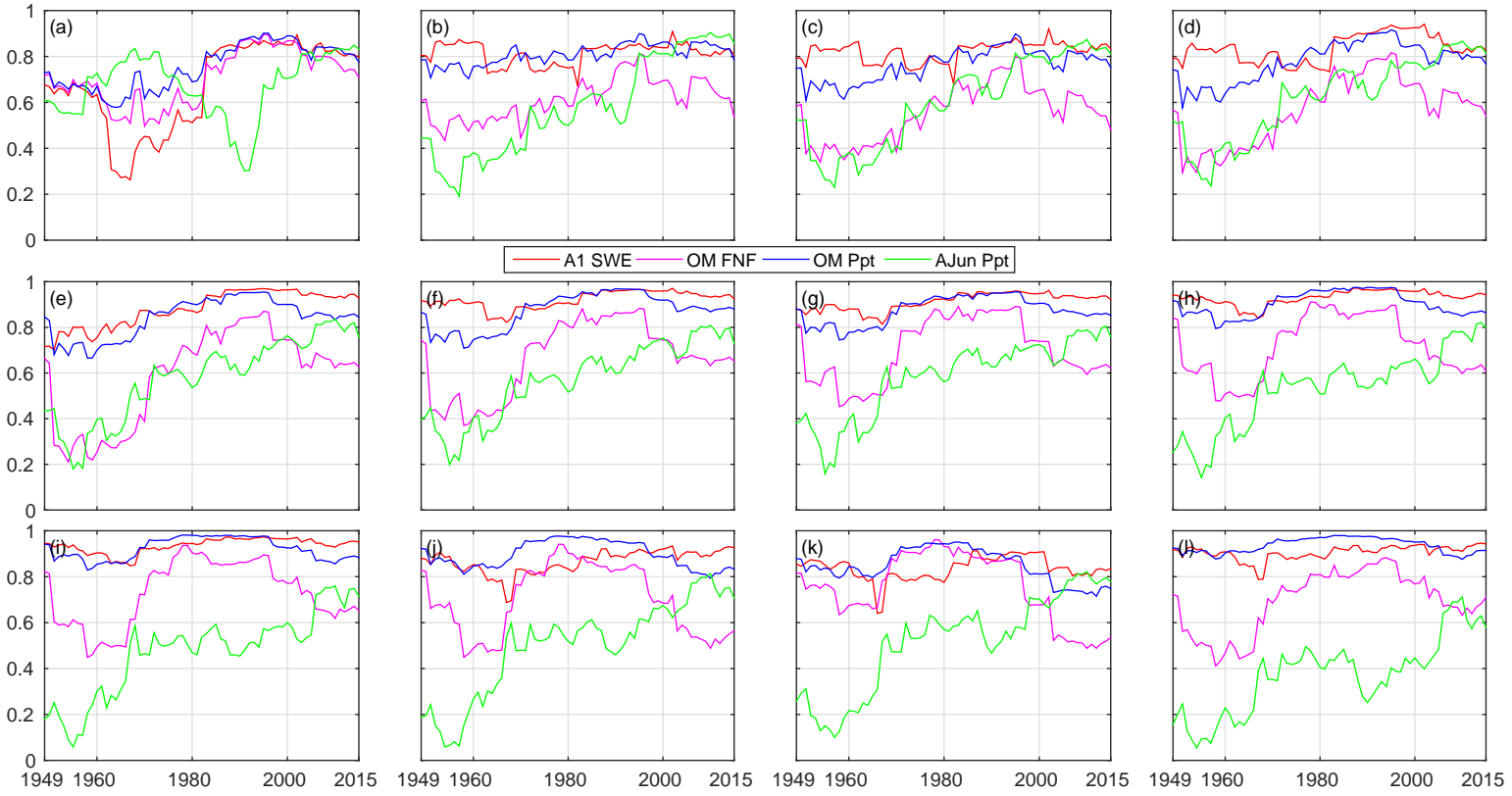

Figure 7. Time series of the 20-year moving window of correlation between predictand April-July runoff (AJ FNF) and predictors including 1 April SWE (A1 SWE), October-March runoff (OM FNF), October-March precipitation (OM Ppt) and April-June (AJun Ppt) for study watersheds (a) SBB; (b) FTO; (c) YRS; (d) AMF; (e) SNS; (f) TLG; (g) MRC; (h) SJF; (i) KGF; (j) KWT; (k) SCC; (1) KRI. The $\mathrm{X}$-axis and $\mathrm{Y}$-axis show the end-year of the moving window and the correlation value, respectively.

Figure 7 further shows an evident increasing trend in the correlation between AJ FNF and AJun Ppt. For other predictors, however, no trends are intuitively notable. The Mann-Kendall Trend-Free Pre-Whitening procedure is applied to determine if significant trends exist in these predictors. The slopes of significant trends identified are presented (Figure 8). To explore the impact of moving window size on the trend, a range of sizes ranging from 20-year to 60-year are investigated. Predictability from A1 SWE generally shows an increasing tendency for all watersheds with a few exceptions (Figure 8a). Specifically, the Feather River Watershed (FTO) exhibits a slight increasing trend (0.005/decade) in the correlation between its AJ FNF and A1 SWE when a 30-year moving window is applied. The Tule River Watershed (SCC) shows positive trends at all window sizes except 
for the 20-year one. As for the predictability from OM FNF, most watersheds exhibit increasing trends at most window-sizes (Figure 8b). However, two watersheds in the Tulare Hydrologic Region (KWT and SCC) exhibit decreasing tendency. These two watersheds also show decreasing trends in the predictability coming from OM Ppt (Figure 8c). Additionally, no change is identified at any window size for the Kern River Basin (KRI). Regarding the predictability contributed from AJun Ppt, upward tendency is evident for all basins at almost all window sizes. In general, the increasing rate is the most (least) significant at FTO (SBB), in contrast to the case with the predictability coming from A1 SWE.

(a) A1 SWE

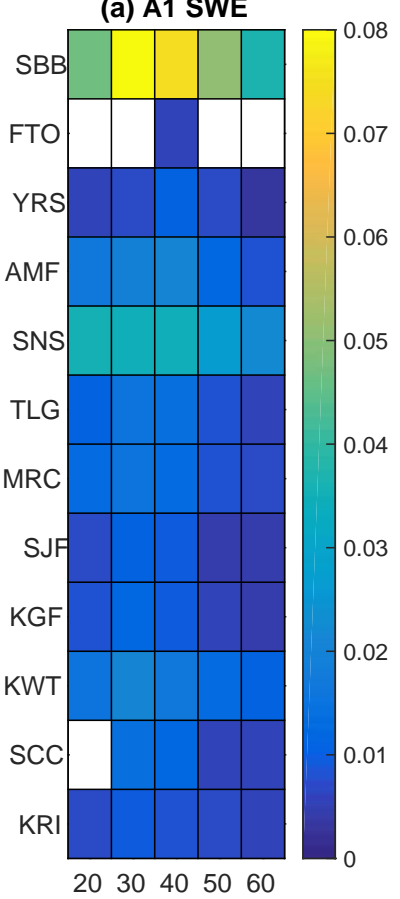

(b) OM FNF

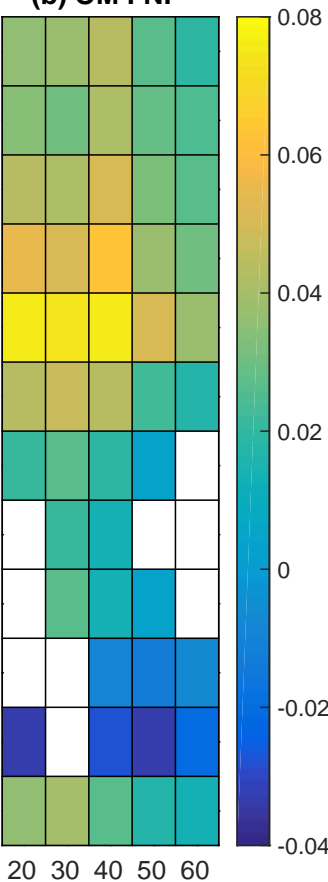

(c) OM Ppt

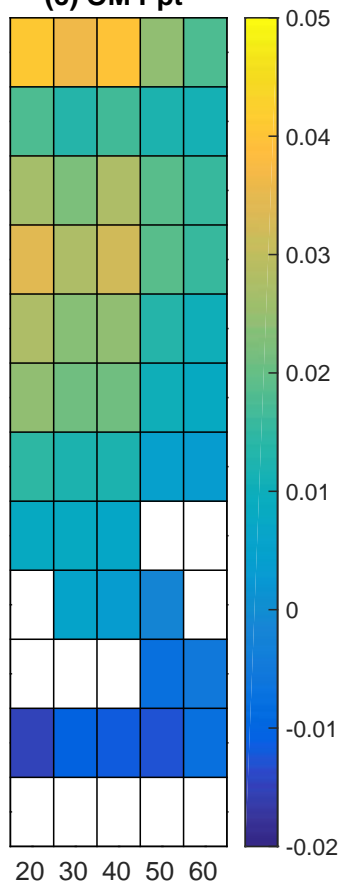

(d) AJun Ppt

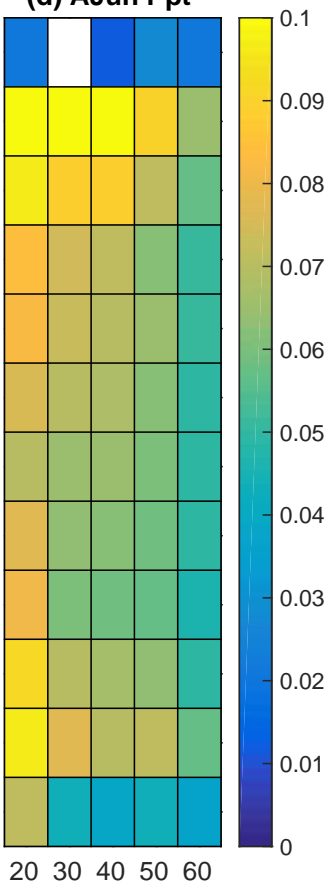

Figure 8. Slope (/decade) of significant trends in the predictability attributed from (a) 1 April snow water equivalent (A1 SWE); (b) October-March runoff (OM FNF); (c) October-March precipitation (OM Ppt); (d) April-June precipitation (AJun Ppt). The white color indicates no statistically significant trends. The $\mathrm{X}$-axis and $\mathrm{Y}$-axis show the moving-window size (in years) and study watersheds, respectively.

The trend is further investigated at the regional scale with the regional trend slope determined by averaging the slopes of identified significant trends at individual watersheds located in each of the three hydrologic regions (Figure 9). The study area is also examined as a whole (designated by green lines in Figure 9) by averaging the slopes of trends of all watersheds where increasing or decreasing tendency exists. In general, the Sacramento Region and San Joaquin Region exhibit positive trends in predictability contributed from each single predictor at all window sizes. It is also the case when looking at all study watersheds together (green lines). Relatively speaking, the increasing rate at the Sacramento Region is the most significant. For the Tulare Region, however, trends in the predictability coming from OM FNF (Figure 9b) and OM Ppt (Figure 9c) are not consistently upwards. This is caused by the downward trends observed at watersheds KWT and SCC (Figure 8b,c). Overall, the increasing or decreasing trend slope becomes milder with increasing window size, which is also the case for individual watersheds exhibiting trends at all window sizes (Figure 8). 

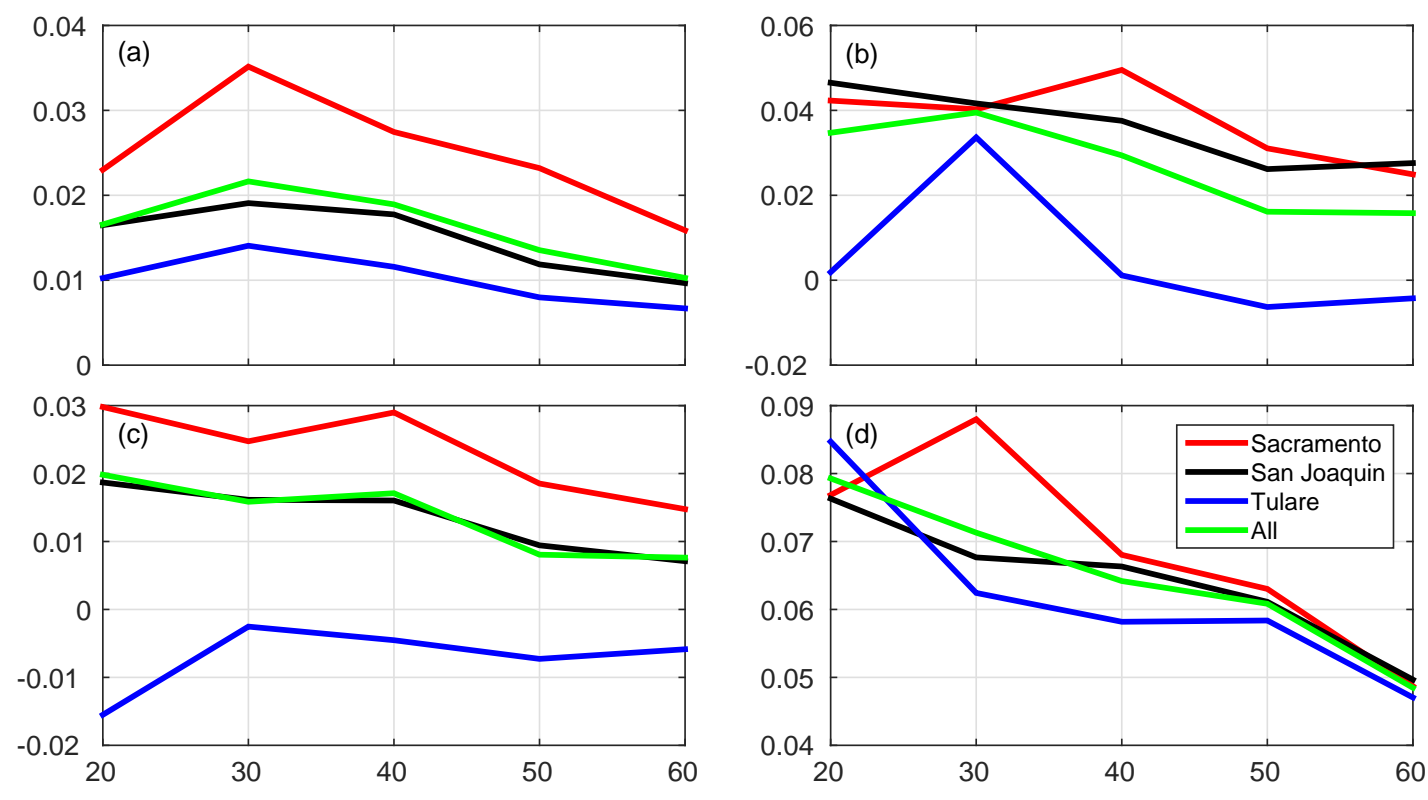

Figure 9. Slope (/decade) of significant trends in the predictability attributed from (a) 1 April snow water equivalent (A1 SWE); (b) October-March runoff (OM FNF); (c) October-March precipitation (OM Ppt); (d) April-June precipitation (AJun Ppt) at the regional scale. The X-axis and Y-axis show the moving-window size (in years) and averaged trend slope, respectively.

In brief, among the four operational predictors, A1 SWE and OM Ppt are major predictors since they are highly correlated with the predictand. In comparison, the predictability coming from AJun Ppt is the weakest. However, the increasing tendency in the predictability contributed from AJun Ppt is the most significant and most consistent across different study watersheds at different window sizes. Increasing tendency is also observed in the predictability from A1 SWE for most watersheds at most window sizes. However, the increasing rate is much smaller than that of the AJun Ppt (Figure 9d). Two watersheds in the Tulare Region exhibit downward trends in the predictability attributed from OM FNF and OM Ppt, leading to downward region-wide trends at some window sizes. When looking at the Sacramento Region, San Joaquin Region, and all study watersheds together, however, the increasing trends is consistent at all window sizes. The increasing rate generally decreases with increasing window size.

\subsection{Predictability from Potential Predictors}

The predictability from potential predictors including the standardized indices and large-scale climate indices described in Section 2.2 are first assessed in this sub-section. Based on the assessment results, changes in the predictability are examined next. The correlation coefficients between the raw observations of AJ FNF and its four operational predictors are calculated in the whole study period (water years 1930-2015), along with the correlation coefficients between the standardized AJ FNF index with the standardized indices determined from these predictors (Figure 10). It is evident that, the correlation values associated with the standardized indices (dark bar) are generally higher than their counterparts associated with the raw data (grey bar) for A1 SWE, OM FNF and OM Ppt (Figure 10a-c). Specifically, the difference is the most notable for OM FNF with the increasing percentage value ranging from $2.4 \%$ (FTO) to $11.7 \%$ (SNS) (Figure 10b). It is a different case for predictor AJun Ppt (Figure 10d). The correlation values between the standardized AJ FNF and standardized AJun Ppt are smaller (ranging from $-15.4 \%$ at SBB to $-4.6 \%$ at SCC) than their counterparts of the raw data. Given the fact that A1 SWE and OM Ppt are the major predictor while AJun Ppt has the weakest predictability for AJ FNF, these observations imply that using standardized indices has the potential of improving 
the predictability of AJ FNF. The trend in the predictability based on the standard indices will thus be explored later in this sub-section.

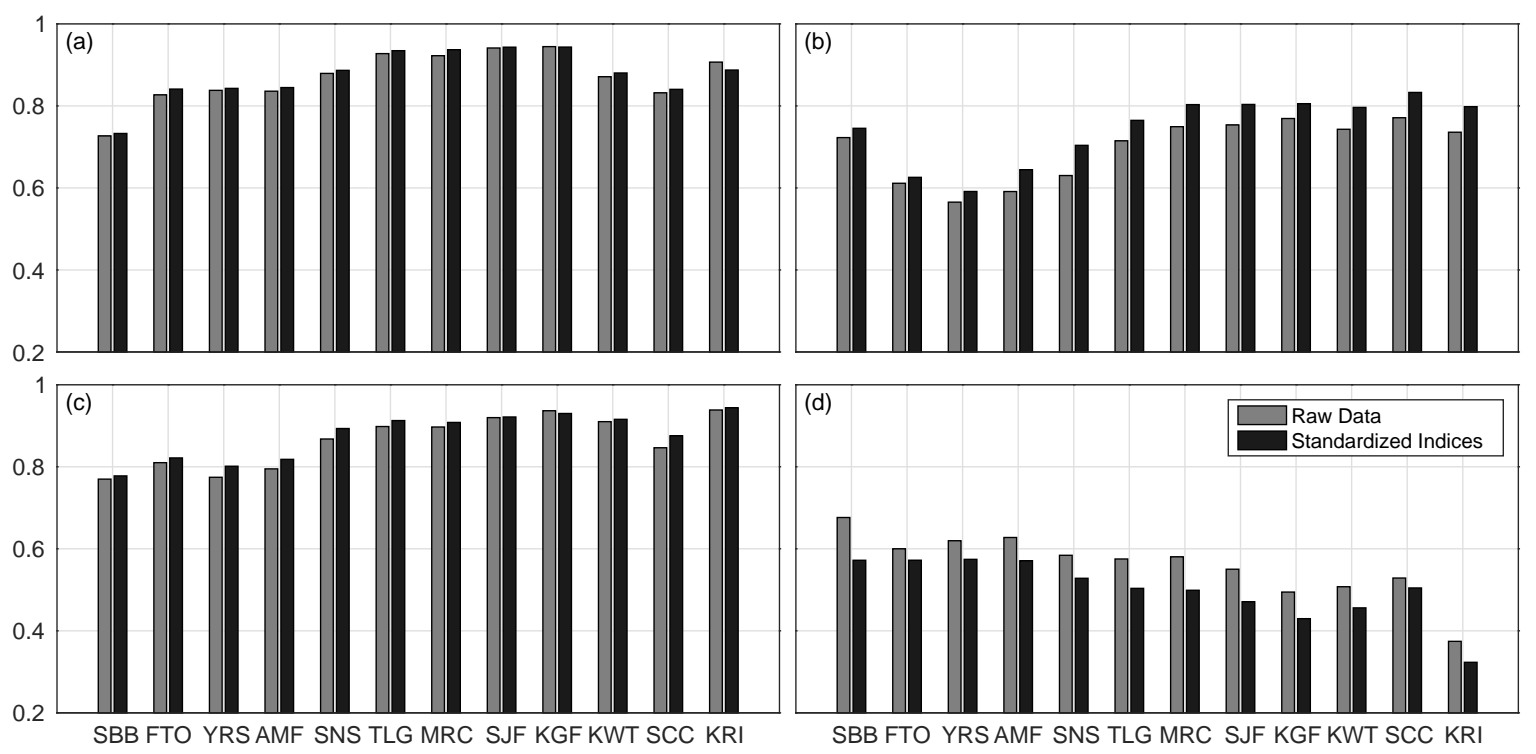

Figure 10. Pearson correlation coefficients (grey bar) between April-July runoff (AJ FNF) and operational predictors including (a) 1 April snow water equivalent (A1 SWE); (b) October-March runoff (OM FNF); (c) October-March precipitation (OM Ppt); (d) April-June precipitation (AJun Ppt) in the study period. Also shown are the correlations (dark bar) between the standardized AJ FNF index and standardized indices determined from each operational predictor in the study period (water years 1930-2015). The X-axis and Y-axis show the study watersheds and correlation coefficients, respectively.
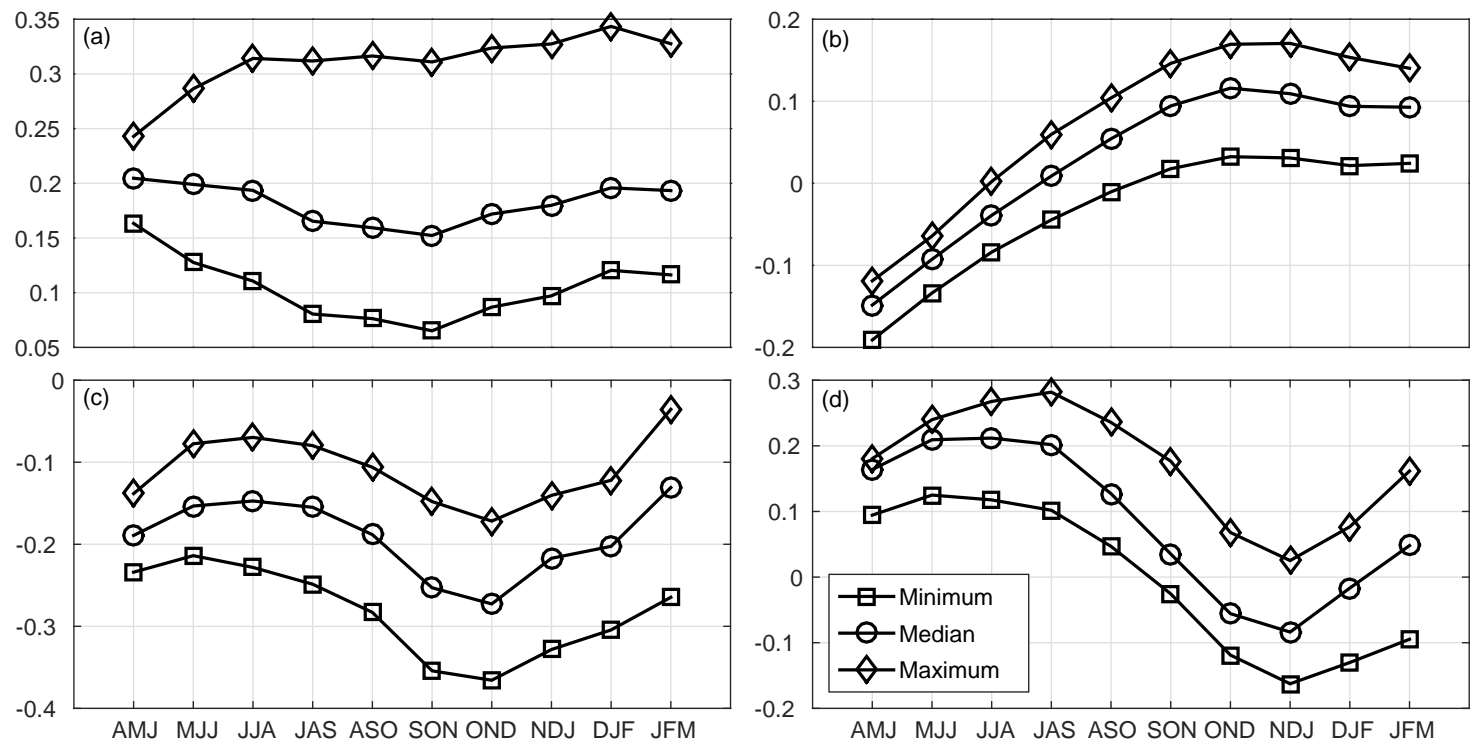

Figure 11. Pearson correlation coefficients between April-July runoff (AJ FNF) observations and the moving three-month average (a) Niño 3.4; (b) Trans-Niño Index (TNI)); (c) Southern Oscillation Index (SOI); (d) Pacific Decadal Oscillation (PDO) in the study period (water years 1930-2015). The X-axis and $\mathrm{Y}$-axis show the three month period and correlation coefficients, respectively.

The correlation coefficients between AJ FNF and moving three-month large-scale climate indices (Niño 3.4, TNI, SOI, and PDI) are calculated for all 12 study watersheds in the entire study period from water year 1930-2015. The maximum, median, and minimum correlation values of these study 
watersheds are illustrated (Figure 11). It is clear that all watersheds exhibit positive correlation with only Niño 3.4 (Figure 11a) among four climate indices at all lead times. In contrast, the correlation with PDO (Figure 11c) is mostly negative. On average, the correlation values with Niño 3.4 (positive) and PDO (negative) are relatively stronger when focusing on the median correlation. Regardless, the absolute correlation coefficients are consistently less than 0.4 for all four climate indices at all lead times investigated. This value is significantly smaller than the correlation values of the operational predictors as well as the standardized indices (Figure 10). This implies that climate indices most likely have no significant potential in enhancing the current operational seasonal streamflow forecasting. The trend in their predictability will not be discussed in this study.

Similar to the predictability of AJ runoff attributed from A1 SWE (Figure 8a), the predictability of standardized AJ runoff index coming from the standardized A1 SWE index is increasing for most study watersheds at most window sizes (Figure 12a). However, watershed FTO has a decreasing trend (with a slope of -0.01 /decade) when a 60-year window size is applied. No decreasing tendency is detected in the predictability coming from the standardized OM runoff index (Figure 12b), different from its raw data counterpart where two Tulare watersheds exhibit decreasing trend (Figure 8b). As for the predictability contributed from the standardized OM precipitation index, four watersheds in the Tulare Region show no changes when 20-year is used as the window size. A total of seven watersheds exhibit no trends neither when looking at the 60-year window size. In other cases, increasing tendency is generally observed with one exception being the KRI where a decreasing trend is detected at the 60-year window size. In comparison, the predictability of AJ runoff coming from OM Ppt for SCC is consistently decreasing at all window sizes investigated; for KRI, no significant trend exists at any window size (Figure 8c). The predictability of standardized AJ runoff index coming from the standardized AJun precipitation index is increasing for most study watersheds at most window sizes (Figure 12d), which is similar to the predictability of AJ runoff contributed from AJun Ppt (Figure 8d). However, the increasing rate in the former is not as significant as the latter.

(a) A1 SSI

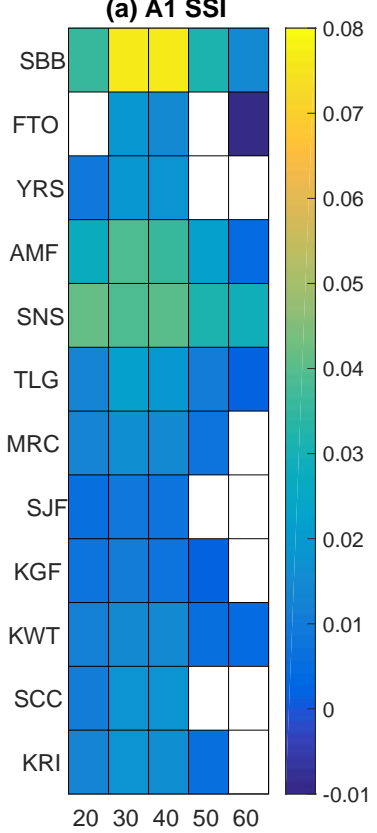

(b) OM SRI

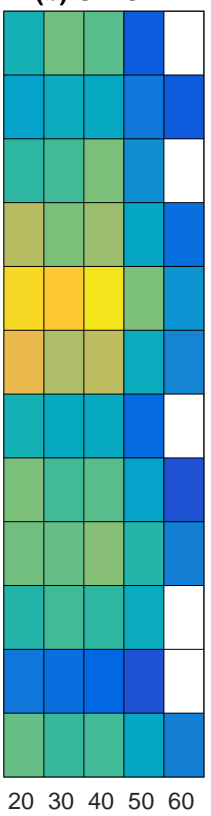

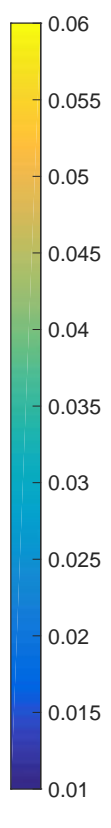

(c) OM SPI

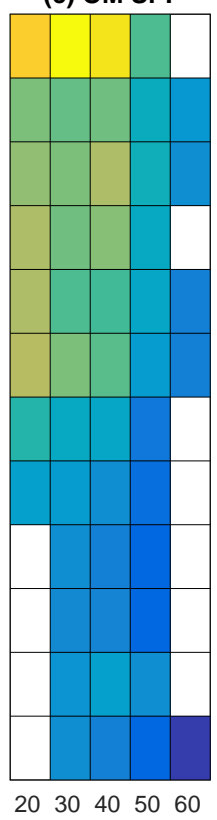

(d) AJun SPI

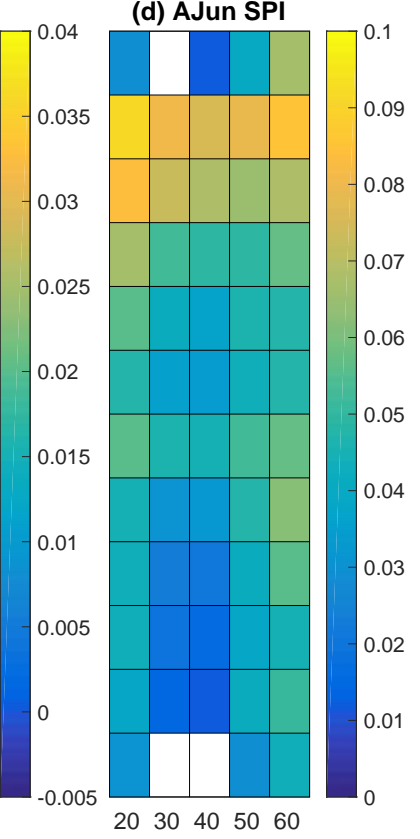

Figure 12. Slope (/decade) of significant trends in the predictability of standardized April-July runoff index (AJ SRI) attributed from (a) standardized 1 April snow water equivalent index (A1 SSI); (b) standardized October-March runoff index (OM SRI); (c) standardized October-March precipitation index (OM SPI); (d) standardized April-June precipitation index (AJun SPI). The white color indicates no statistically significant trends. The $\mathrm{X}$-axis and $\mathrm{Y}$-axis show the moving-window size (in years) and study watersheds, respectively. 
In short, the correlations between the standardized AJ runoff index and the standardized A1 SWE index as well as the standardized OM precipitation index are generally higher than their counterparts when the raw data is examined. This highlights the implication of these standardized indices in enhancing the current operational regression equations in providing more reliable seasonal streamflow forecasts, particularly in light of the observation that A1 SWE and OM precipitation are the major predictors for AJ runoff. The large-scale climate indices typically applied in predicting seasonal streamflow in previous studies, in contrast, have significantly smaller correlation with AJ runoff than the current operational predictors. Comparing to the standardized indices, these climate indices are less likely to improve the current forecasting. In general, increasing tendency in the predictability of the standardized AJ runoff index coming from different standardized predictors is notable for most watersheds at most window-sizes.

\section{Discussion and Conclusions}

In line with previous studies that report increasing trends in temperature across California [27,28,73-75], this study identifies general upward trends in watershed-wide minimum temperature and average temperature across annual, seasonal and monthly scales. Particularly, the trend in the minimum temperature is more consistent (across study watersheds) and significant (in terms of increasing rate). However, this study detects limited upward trend in the maximum temperature. Given the fact that the study basins are all snow impacted, increasing in minimum temperature most likely elevates the rain-snow dividing line and leads to more precipitation falling as rain rather than snow in these areas. This study further shows that there is generally no change in annual, seasonal, and monthly precipitation in the study watersheds. This finding is consistent with what is shown in previous studies [22,31,76]. A new finding of this study is that the April-July runoff volumes of the study watersheds show no sign of changes in the study period. It is also the case for four operational predictors (i.e., 1 April snow water equivalent, October-March precipitation and runoff, April-June precipitation). This highlights that though the occurrence frequency of extreme storm and runoff events may be increasing as reported in previous work [31,77-79], their total volume at a longer temporal scale (multi-monthly) remains largely unchanged. The practical implication of this finding is that the current operational regression equations are still valid and usable since both the predictand and predictors are stationary so far. Nevertheless, it should be pointed out that declining trend in Sierra Nevada snowpack has been reported in previous work $[12,80,81]$, which is contrary to the finding of the current study. This contrast is most likely caused by the differences in the spatial scale of the dataset and trend analysis method between the current and previous work. Specifically, this study utilizes operational watershed-scale snow water equivalent data (versus point or grid scale typically adopted in previous work) and the Mann-Kendall Trend-Free Pre-Whitening trend analysis procedure (versus traditional linear regression trend analysis method).

Despite no trends detected in the predictand and its predictors, in another new finding, this study shows that they generally become more variable in terms of exhibiting increasing tendency in their variabilities. Overall, the increasing trend in the flow variability (April-July and October-March runoff) is more consistent and significant than in the precipitation (October-March and April-June) and snow (1 April snow water equivalent). This indicates that though the increasing minimum temperature and average temperature have not explicitly led to changes in the amount of snowpack (peak) and runoff (multi-monthly), they generally lead to increasing variability in those variables. This is in agreement with what have been previously found out in precipitation with increasing variability but no significant changes to the mean value $[31,82,83]$. The implication is that the occurrence frequency of extreme events is increasing. The current water resources (particularly flood and drought) planning and management practices should be adapted to reflect this change. Additionally, this study finds out that the predictability of April-July runoff contributed from four operational predictors is generally increasing, particularly for April-June precipitation. This is likely due to the fact that more precipitation during April-June falls as rainfall rather than snowfall due to warming in Spring and early Summer 
(Figure 5). Comparing to snowfall which contributes to evaporation, infiltration, and runoff in a slow process, rainfall largely contributes to April-July runoff directly. However, the specific changing rate varies with different predictors across different watersheds at different moving-window sizes. Specifically, the increasing rate is the highest in Sacramento watersheds and typically decreases with increasing moving-window size. The practical implication of this finding is twofold. First, it can help improve the current regression equations in terms of adjusting the weight assigned to each predictor in response to the changing climate. Second, it can guide the efforts in investing more on watersheds with relatively lower predictability.

Another new finding of this study is that standardized precipitation (October-March), runoff (October-March) and snow (1 April snow water equivalent) indices show higher predictability than their raw precipitation and snow counterparts, while the large-scale climate indices have relatively lower predictability compared to the current operational predictors. In general the predictability coming from the standardized precipitation, runoff, and snow indices is also increasing in the study period. These standardized indices hold great scientific implication for improved seasonal streamflow forecasting in the context of incorporating them into the current regression equations as new predictors or developing new forecasting equations (models) based on them. The operational applicability of these standardized indices is under evaluation and will be reported in our future work.

In spite of its popularity among researcher [69-72], the linear Pearson correlation coefficient applied in this study may not be a perfect proxy for predictability. When high non-linearity exists between the predictand and predictors, alternative metrics should be evaluated. It should also been highlighted that, when looking at changes in predictability on the regional scale, only basins exhibiting significant trends (at a significance level of 0.05) are considered in determining the regional changes, while the basins showing no significant trends at the same significance level are accounted out. Ideally, the region-wide variable (e.g., runoff) should be aggregated first and the predictability of the aggregated value can be determined afterwards. A more comprehensive analysis at the regional scale will be presented in our future work.

In a nut shell, the findings of this study are meaningful from both theoretical and practical perspectives in terms of guiding the development of new forecasting models and enhancing the current operational forecasting model, respectively, for improved seasonal streamflow forecasting in a changing climate.

Acknowledgments: The authors would like to thank Mahesh Gautam for providing Matlab script for the Mann-Kendall Trend-Free Pre-Whitening procedure. The authors thank Hyun-Min Shin and Angelique Fabbiani-Leon for their help with processing the PRISM data. The authors also appreciate the discussion with Stephen Nemeth and John King on the full natural flow and snow data. The authors would also like to thank the editor and two anonymous reviewers for their valuable comments that helped improve the quality of this study. Any findings, opinions and conclusions expressed in this paper are solely the authors' and do not reflect the views or opinions of their employer.

Author Contributions: The study was conceived by the authors together. Minxue He conducted the study and wrote the paper. Mitchel Russo and Michael Anderson provided critical discussions.

Conflicts of Interest: The authors declare no conflict of interest.

\section{References}

1. Twedt, T.M.; Burnash, R.J.C.; Ferral, R.L. Extended streamflow prediction during the California drought. In Proceedings of the 46th Annual Western Snow Conference, Otter Rock, OR, USA, 7-14 April 1978.

2. Krzysztofowicz, R. Optimal water supply planning based on seasonal runoff forecasts. Water Resour. Res. 1986, 22, 313-321. [CrossRef]

3. Krzysztofowicz, R. Expected utility, benefit, and loss criteria for seasonal water supply planning. Water Resour. Res. 1986, 22, 303-312. [CrossRef]

4. Brumbelow, K.; Georgakakos, A. Agricultural planning and irrigation management: The need for decision support. Clim. Rep. 2001, 1, 2-6. 
5. Hayes, M.; Svoboda, M.; Le Comte, D.; Redmond, K.T.; Pasteris, P. Drought monitoring: New tools for the 21st century. In Drought and Water Crises: Science, Technology, and Management Issues; Wilhite, D.A., Ed.; CRC Press: Boca Raton, FL, USA, 2005; p. 53.

6. Smith, J.A.; Sheer, D.P.; Schaake, J. Use of hydrometeorological data in drought management: Potomac River basin case study. In Proceedings of the American Water Resources Association, Denver, CO, USA, 13-17 June 1982.

7. Sheer, D.P. Analyzing the risk of drought: The occoquan experience. J. Am. Water Works Ass. 1980, 72, 246-253.

8. Yao, H.; Georgakakos, A. Assessment of Folsom Lake response to historical and potential future climate scenarios: 2. Reservoir management. J. Hydrol. 2001, 249, 176-196. [CrossRef]

9. Hamlet, A.F.; Huppert, D.; Lettenmaier, D.P. Economic value of long-lead streamflow forecasts for Columbia River hydropower. J. Water Resour. Plan. Manage. 2002, 128, 91-101. [CrossRef]

10. Maurer, E.P.; Lettenmaier, D.P. Potential effects of long-lead hydrologic predictability on Missouri River main-stem reservoirs. J. Clim. 2004, 17, 174-186. [CrossRef]

11. Cayan, D.R.; Dettinger, M.D.; Kammerdiener, S.A.; Caprio, J.M.; Peterson, D.H. Changes in the onset of spring in the Western United States. B. Am. Meteorol. Soc. 2001, 82, 399-415. [CrossRef]

12. Mote, P.W.; Hamlet, A.F.; Clark, M.P.; Lettenmaier, D.P. Declining mountain snowpack in Western North America. B. Am. Meteorol. Soc. 2005, 86, 39-49. [CrossRef]

13. Regonda, S.K.; Rajagopalan, B.; Clark, M.; Pitlick, J. Seasonal cycle shifts in hydroclimatology over the Western United States. J. Clim. 2005, 18, 372-384. [CrossRef]

14. Stewart, I.T.; Cayan, D.R.; Dettinger, M.D. Changes in snowmelt runoff timing in Western North America under a 'business as usual' climate change scenario. Clim. Change 2004, 62, 217-232. [CrossRef]

15. Pagano, T.; Garen, D.; Sorooshian, S. Evaluation of official Western US seasonal water supply outlooks, 1922-2002. J. Hydrometeorol. 2004, 5, 896-909. [CrossRef]

16. Harrison, B.; Bales, R. Skill assessment of water supply outlooks in the Colorado River basin. Hydrology 2015, 2, 112-131. [CrossRef]

17. Rosenberg, E.A.; Wood, A.W.; Steinemann, A.C. Statistical applications of physically based hydrologic models to seasonal streamflow forecasts. Water Resour. Res. 2011. [CrossRef]

18. Zuzel, J.F.; Cox, L.M. A review of operational water supply forecasting techniques in areas of seasonal snowcover. In Proceedings of the 46th Annual Western Snow Conference, Otter Rock, OR, USA, 7-14 April 1978.

19. Huber, A.L.; Robertson, D.C. Regression models in water supply forecasting. In Proceedings of the 50th Annual Western Snow Conference, Reno, NV, USA, 19-23 April 1982.

20. Garen, D.C. Improved techniques in regression-based streamflow volume forecasting. J. Water Resour. Plan. Manage. 1992, 118, 654-670. [CrossRef]

21. Svensson, C. Seasonal river flow forecasts for the United Kingdom using persistence and historical analogues. Hydrol. Sci. J. 2014. [CrossRef]

22. Grundstein, A. Evaluation of climate change over the continental United States using a moisture index. Clim. Change 2009, 93, 103-115. [CrossRef]

23. Pryor, S.; Howe, J.; Kunkel, K. How spatially coherent and statistically robust are temporal changes in extreme precipitation in the contiguous USA? Int. J. Climatol. 2009, 29, 31-45. [CrossRef]

24. Grundstein, A.; Dowd, J. Trends in extreme apparent temperatures over the United States, 1949-2010. J. Appl. Meteorol. Clim. 2011, 50, 1650-1653. [CrossRef]

25. Hoerling, M.P.; Dettinger, M.; Wolter, K.; Lukas, J.; Eischeid, J.; Nemani, R.; Liebmann, B.; Kunkel, K.E.; Kumar, A. Present weather and climate: Evolving conditions. In Assessment of Climate Change in the Southwest United States; Springer: Berlin, Germany, 2013; pp. 74-100.

26. Schwartz, M.D.; Ault, T.R.; Betancourt, J.L. Spring onset variations and trends in the continental United States: Past and regional assessment using temperature-based indices. Int. J. Climatol. 2013, 33, 2917-2922. [CrossRef]

27. Bonfils, C.; Duffy, P.B.; Santer, B.D.; Wigley, T.M.; Lobell, D.B.; Phillips, T.J.; Doutriaux, C. Identification of external influences on temperatures in California. Clim. Change 2008, 87, 43-55. [CrossRef] 
28. Bonfils, C.; Santer, B.D.; Pierce, D.W.; Hidalgo, H.G.; Bala, G.; Das, T.; Barnett, T.P.; Cayan, D.R.; Doutriaux, C.; Wood, A.W.; et al. Detection and attribution of temperature changes in the mountainous Western United States. J. Clim. 2008, 21, 6404-6424. [CrossRef]

29. Wang, H.; Schubert, S.; Suarez, M.; Chen, J.; Hoerling, M.; Kumar, A.; Pegion, P. Attribution of the seasonality and regionality in climate trends over the United States during 1950-2000. J. Clim. 2009, 22, 2571-2590. [CrossRef]

30. Westby, R.M.; Lee, Y.Y.; Black, R.X. Anomalous temperature regimes during the cool season: Long-term trends, low-frequency mode modulation, and representation in CMIP5 simulations. J. Clim. 2013, 26, 9061-9076. [CrossRef]

31. He, M.; Gautam, M. Variability and trends in precipitation, temperature and drought indices in the State of California. Hydrology 2016. [CrossRef]

32. Redmond, K.T.; Koch, R.W. Surface climate and streamflow variability in the Western United States and their relationship to large-scale circulation indices. Water Resour. Res. 1991, 27, 2381-2399. [CrossRef]

33. Moradkhani, H.; Meier, M. Long-lead water supply forecast using large-scale climate predictors and independent component analysis. J. Hydrol. Eng. 2010, 15, 744-762. [CrossRef]

34. Kennedy, A.M.; Garen, D.C.; Koch, R.W. The association between climate teleconnection indices and upper Klamath seasonal streamflow: Trans-Niño index. Hydrol. Process. 2009, 23, 973-984. [CrossRef]

35. Opitz-Stapleton, S.; Gangopadhyay, S.; Rajagopalan, B. Generating streamflow forecasts for the Yakima River basin using large-scale climate predictors. J. Hydrol. 2007, 341, 131-143. [CrossRef]

36. Tootle, G.A.; Piechota, T.C. Relationships between Pacific and Atlantic ocean sea surface temperatures and US streamflow variability. Water Resour. Res. 2006. [CrossRef]

37. Tootle, G.A.; Piechota, T.C. Suwannee river long range streamflow forecasts based on seasonal climate predictors. J. Am. Water Resour. Assoc. 2004, 40, 523-532. [CrossRef]

38. Soukup, T.L.; Aziz, O.A.; Tootle, G.A.; Piechota, T.C.; Wulff, S.S. Long lead-time streamflow forecasting of the North Platte River incorporating oceanic-atmospheric climate variability. J. Hydrol. 2009, 368, 131-142. [CrossRef]

39. Chiew, F.H.; Piechota, T.C.; Dracup, J.A.; McMahon, T.A. El Nino/Southern Oscillation and australian rainfall, streamflow and drought: Links and potential for forecasting. J. Hydrol. 1998, 204, 138-149. [CrossRef]

40. Piechota, T.C.; Chiew, F.H.; Dracup, J.A.; McMahon, T.A. Seasonal streamflow forecasting in Eastern Australia and the El Niño-Southern Oscillation. Water Resour. Res. 1998, 34, 3035-3044. [CrossRef]

41. Piechota, T.C.; Dracup, J.A. Long-range streamflow forecasting using El Niño-Southern Oscillation indicators. J. Hydrol. Eng. 1999, 4, 144-151. [CrossRef]

42. Hamlet, A.F.; Lettenmaier, D.P. Columbia river streamflow forecasting based on ENSO and PDO climate signals. J. Water Resour. Plan. Manage. 1999, 125, 333-341. [CrossRef]

43. Robertson, D.E.; Wang, Q.J. A Bayesian approach to predictor selection for seasonal streamflow forecasting. J. Hydrometeorol. 2012, 13, 155-171. [CrossRef]

44. Karamouz, M.; Zahraie, B. Seasonal streamflow forecasting using snow budget and El Niño-Southern Oscillation climate signals: Application to the Salt River basin in Arizona. J. Hydrol. Eng. 2004, 9, 523-533. [CrossRef]

45. Carbone, G.J.; Dow, K. Water resource management and drought forecasts in South Carolina. J. Am. Water Resour. Assoc. 2005, 41, 145-155. [CrossRef]

46. Trenberth, K.E.; Stepaniak, D.P. Indices of El Niño evolution. J. Clim. 2001, 14, 1697-1701. [CrossRef]

47. Wolter, K. The Southern Oscillation in surface circulation and climate over the tropical Atlantic, Eastern Pacific, and Indian oceans as captured by cluster analysis. J. Clim. Appl. Meteorol. 1987, 26, 540-558. [CrossRef]

48. Wallace, J.M.; Gutzler, D.S. Teleconnections in the geopotential height field during the northern hemisphere winter. Mon. Weather Rev. 1981, 109, 784-812. [CrossRef]

49. Mantua, N.J.; Hare, S.R.; Zhang, Y.; Wallace, J.M.; Francis, R.C. A Pacific interdecadal climate oscillation with impacts on salmon production. B. Am. Meteorol. Soc. 1997, 78, 1069-1079. [CrossRef]

50. Keyantash, J.; Dracup, J.A. The quantification of drought: An evaluation of drought indices. B. Am. Meteorol. Soc. 2002, 83, 1167-1180.

51. Heim, R.R., Jr. A review of twentieth-century drought indices used in the United States. B. Am. Meteorol. Soc. 2002, 83, 1149-1165. 
52. Dai, A. Drought under global warming: A review. WIREs Clim. Change 2011, 2, 45-65. [CrossRef]

53. McKee, T.B.; Doesken, N.J.; Kleist, J. The relationship of drought frequency and duration to time scales. In Proceedings of the 8th Conference on Applied Climatology, Anaheim, CA, USA, 17-22 January 1993.

54. Shukla, S.; Wood, A.W. Use of a standardized runoff index for characterizing hydrologic drought. Geophys. Res. Lett. 2008. [CrossRef]

55. Guttman, N. Accepting the standardized precipitation index: A calculation algorithm. J. Am. Water Resour. Assoc. 1999, 35, 311-322. [CrossRef]

56. Quiring, S.M. Developing objective operational definitions for monitoring drought. J. Appl. Meteorol. Climatol. 2009, 48, 1217-1229. [CrossRef]

57. Farahmand, A.; AghaKouchak, A. A generalized framework for deriving nonparametric standardized drought indicators. Adv. Water Resour. 2015, 76, 140-145. [CrossRef]

58. Mann, H. Non-parametric tests against trend. Econometrica 1945, 13, 245-259. [CrossRef]

59. Kendall, M.G. Rank Correlation Methods; Charles Griffin: London, UK, 1975.

60. Thiel, H. A rank-invariant method of linear and polynomial regression analysis, part 3. In Advanced Studies in Theoretical and Applied Econometrics; Springer: Berlin, Germany, 1992; pp. 345-381.

61. Sen, P.K. Estimates of the regression coefficient based on Kendall's tau. J. Am. Stat. Assoc. 1968, 63, 1379-1389. [CrossRef]

62. von Storch, H. Misuses of statistical analysis in climate research. In Analysis of Climate Variability; Springer: Berlin, Germany, 1995; pp. 11-26.

63. Douglas, E.; Vogel, R.; Kroll, C. Trends in floods and low flows in the United States: Impact of spatial correlation. J. Hydrol. 2000, 240, 90-105. [CrossRef]

64. Hamed, K.H.; Rao, A.R. A modified Mann-Kendall trend test for autocorrelated data. J. Hydrol. 1998, 204, 182-196. [CrossRef]

65. Yue, S.; Pilon, P.; Phinney, B. Canadian streamflow trend detection: Impacts of serial and cross-correlation. Hydrolog. Sci. J. 2003, 48, 51-63. [CrossRef]

66. Yue, S.; Pilon, P.; Phinney, B.; Cavadias, G. The influence of autocorrelation on the ability to detect trend in hydrological series. Hydrol. Process. 2002, 16, 1807-1829. [CrossRef]

67. Yue, S.; Wang, C.Y. Applicability of prewhitening to eliminate the influence of serial correlation on the mann-kendall test. Water Resour. Res. 2002, 38. [CrossRef]

68. Pagano, T.; Garen, D. A recent increase in Western US streamflow variability and persistence. J. Hydrometeorol. 2005, 6, 173-179. [CrossRef]

69. Luo, L.; Wood, E.F. Assessing the idealized predictability of precipitation and temperature in the NCEP Climate Forecast System. Geophys. Res. Lett. 2006. [CrossRef]

70. Waliser, D.; Lau, K.; Stern, W.; Jones, C. Potential predictability of the Madden-Julian Oscillation. B. Am. Meteorol. Soc. 2003. [CrossRef]

71. Lavers, D.A.; Waliser, D.E.; Ralph, F.M.; Dettinger, M.D. Predictability of horizontal water vapor transport relative to precipitation: Enhancing situational awareness for forecasting Western US extreme precipitation and flooding. Geophys. Res. Lett. 2016, 43, 2275-2282. [CrossRef]

72. Kumar, A.; Peng, P.; Chen, M. Is there a relationship between potential and actual skill? Mon. Weather Rev. 2014, 142, 2220-2227. [CrossRef]

73. Cordero, E.C.; Kessomkiat, W.; Abatzoglou, J.; Mauget, S.A. The identification of distinct patterns in California temperature trends. Clim. Change 2011, 108, 357-382. [CrossRef]

74. MacDonald, G.M. Water, climate change, and sustainability in the southwest. Proc. Natl. Acad. Sci. USA 2010, 107, 21256-21262. [CrossRef] [PubMed]

75. Walsh, J.; Wuebbles, D.; Hayhoe, K.; Kossin, J.; Kunkel, K.; Stephens, G.; Thorne, P.; Vose, R.; Wehner, M.; Willis, J. Ch. 2: Our changing climate. In Climate Change Impacts in the United States: The Third National Climate Assessment; Melillo, J.M., Yohe, G.W., Eds.; US Global Change Research Program: Washington, DC, USA, 2014; pp. 19-67.

76. Kunkel, K.; Stevens, L.; Stevens, S.; Sun, L.; Janssen, E.; Wuebbles, D.; Kruk, M.; Thomas, D.; Shulski, M.; Umphlett, N. Regional climate trends and scenarios for the US national climate assessment: Part 4. Climate of the US great plains. NOAA Tech. Report NESDIS 2013, 142, 91.

77. Das, T.; Dettinger, M.D.; Cayan, D.R.; Hidalgo, H.G. Potential increase in floods in California's sierra Nevada under future climate projections. Clim. Change 2011, 109, 71-94. [CrossRef] 
78. Tebaldi, C.; Hayhoe, K.; Arblaster, J.M.; Meehl, G.A. Going to the extremes. Clim. Change 2006, 79, $185-211$. [CrossRef]

79. Yoon, J.H.; Wang, S.S.; Gillies, R.R.; Kravitz, B.; Hipps, L.; Rasch, P.J. Increasing water cycle extremes in California and in relation to ENSO cycle under global warming. Nat. Commun. 2015. [CrossRef] [PubMed]

80. Groisman, P.Y.; Knight, R.W.; Karl, T.R.; Easterling, D.R.; Sun, B.; Lawrimore, J.H. Contemporary changes of the hydrological cycle over the contiguous United States: Trends derived from in situ observations. J. Hydrometeorol. 2004, 5, 64-85. [CrossRef]

81. Knowles, N.; Dettinger, M.D.; Cayan, D.R. Trends in snowfall versus rainfall in the Western United States. J. Clim. 2006, 19, 4545-4559. [CrossRef]

82. Berg, N.; Hall, A. Increased interannual precipitation extremes over California under climate change. J. Clim. 2015. [CrossRef]

83. Wang, J.; Zhang, X. Downscaling and projection of winter extreme daily precipitation over North America. J. Clim. 2008, 21, 923-937. [CrossRef]

(C) 2016 by the authors; licensee MDPI, Basel, Switzerland. This article is an open access article distributed under the terms and conditions of the Creative Commons Attribution (CC-BY) license (http://creativecommons.org/licenses/by/4.0/). 